N. 4753 January 7,1961

have been valuable. Perhaps the most elegant use of ion-exchange is in the separation of the lanthanide and actinide elements. This aspect is almost completely ignored. Again, although emphasis is laid on the low conductivity of 'de-ionized' water, particularly by comparison with distilled water, an indication that the conductivity of laboratory distilled water is due almost entirely to dissolved carbon dioxide and ammonia would not have been out of place. Further, the 'de-ionized' water contains significant quantities of organic impurities, some of them surface-active and not detected by conductivity measurements. The film will certainly appeal to many potential users of ion exchange; whether it will appeal to students and research workers remains to be seen. "An Introduction to Ion Exchange" is a $16-\mathrm{mm}$. film with an optical sound track, and runs for $27 \mathrm{~min}$. Jt is available on free loan to learned societies, colleges and schools, industrial associations, etc. ; applications should be sent to the Permutit Co., Ltd., Permutit House, Gunnersbury Avenue, London, W.4.

\title{
SERVICE WITH OVERSEAS GOVERNMENTS
}

$\mathrm{N}$ EW arrangements for service with overseas governments are detailed in a White Paper issued by the Secretary of State for the Colonies*. For reasons indicated in an appendix, the British Government has rejected as impracticable the idea of an Overseas Service based on the United Kingdom. Such a Service would not solve the problem of the future prospects of members of the Overseas Civil Service, but the Government is examining the feasibility of establishing a Commonwealth Advisory and Technical Service as suggested by the Select Committe $\theta$ on Estimates. Under the new arrangements the Government will assume full responsibility for the cost of the inducement element, which is a necessary part of the emoluments of most expatriate officers, and a fresh review of the emoluments of the officers concerned will be necessary in many territories. For purposes of United Kingdom taxation, the additional pension payable to an expatriate officer, which stems from the inducement allowance, will be treated in the same way as existing pension, and the cost of that part of the pension will be borne by the Government. The Government will pay education and children's allowances similar to those payable to members of the Home Civil Service posted. overseas, and will also meet half the passage costs required to enable children being educated outside the territory in which an officer is serving to visit their parents, or to be visited by their mother, once a year. The Government has also contributed to some compensation schemes now in force for loss of career on premature retirement, or taken account of their cost in considering what further financial assistance should be given, and for future schemes will share the cost equally with overseas Governments.

The scheme will come into effect in most territories on April 1, 1961, and will cover up to 21,000 pensionable and contract officers overseas at a cost to the British Government of $£ 12-£ 16$ million a year. Besides all existing Colonies and dependencies, it will be offered to Nigeria, Sierra Loone and Singapore, and to Northern Rhodesia and Nyasaland, but not to the Bahamas, Bermuda, Brunei and Hong Kong, where, for several reasons, this form of help is not regarded as appropriate, at least for the time being. The arrangements have been developed after consultation with overseas governments and staff associations and they are complementary to plans being vigorously pursued for staffing the public services by local

* Colonial Offlce. Service with Overseas Governments. Pr. 22. (Cmnd. 1193.) (London: II.M. Stationery Office, 1960.) is, 3d. net. officers in the territories concerned. The White Paper also emphasizes the value of overseas officers in technical assistance schemes, and a high-level technical assistance working party has been set up under Foreign Office chairmanship as a means of exchanging information and experience between departments and organizations engaged in technical assistance work. A sub-committee of this body will co-ordinate the recruitment activities of the Government for technical assistance posts, and the fullest consideration will be given to retiring and retired members of the Overseas Civil Service for all suitable vacancies. It is also proposed to give greater publicity to the Ovorseas Services Resettlement Bureau, which has already placed more than 1,000 of the 1,710 officers registered with it from July 1957 to mid-October 1960; it is pointed out that the Bureau could prove a very valuable source of man-power to industry and commerce, particularly to export industries seeking men and women with long and detailed knowledge of overseas territories.

As regards the future, the proportion of candidates appointed on contract terms through the Colonial Office has increased markedly in recent years and such appointments now constitute the great majority. Wherever possible the British Government plans to obtain recruits on loan from government departments, public corporations and local authorities, so that individuals can be certain of resuming their previous employment on returning to the United Kingdom. It is also hoped that individual service overseas will be accepted as an asset both to the employer and employee, and that employers will co-operate in facilitating the release of those able and willing to serve overseas and in re-absorbing them on their return.

Further to the above, the Colonial Office has now issued the report of the Public Services Conference held in London during March 1-10, 1960, to exchange information on measures taken or projected to build up local civil services in the African territories, which was initially a confidential document for consideration by the governments represented at the conference* All, however, have since agreed that it should be published, and it has now been issued by the Colonial Office.

The agenda covered the general pooling of experienco and a comparison of the measures adopted; a review of the facilities for sccondary and university

* Colonial Office. Report of the Public Services Conference held in the Colonial Office, London, 1st to 10th March, 1960. Pp. iii +25 . (Colonial $\mathrm{N}$ o. 347.) (London: H.M. Stationery Office, 1960.) 3s. 6d. net. 
education, including a comparison of scholarships schemes, training programmes; the exchange of information; the impact of localization on serving overseas officers; and the staffing problems which arise from the development of ministerial systems. The report makes no specific recommendations for governments to adopt, but indicates the important problems and the lines on which they might be tackled, leaving it for each government to reach its own decision after examining the report in the light of its own local conditions.

The report suggests that each government should make a general roview of the whole range of problems arising from the need to staff the local civil service increasingly with local people and that standing arrangements should be made to keep under consideration the policy as it develops. Discussing the provision of sufficient numbers of educated men and women, the need to provide secondary and higher education before satisfying all the needs of primary education was emphasized at the conference, and it was urged that the balance of secondary and higher educational systems should be planned on the basis of regular authoritative surveys of the estimated needs for educated man-power undertaken by really first-class exporienced persons. As regards courses of training in the United Kingdom, which in 1959 provided for some 2,300 places, more than half of which were taken by local Civil Service officers, the Colonial Office stated that it was very ready to consider the provision of new courses or ad hoc training attachments to meet the requirements of overseas governments. In regard to the training of technicians and especially the training of supervisors in technical work, the conference agreed that no good answer had yet been found to the problem of training supervisors rapidly, and that there was no real substitute for experience on the job. The Colonial Office agreed to undertake the preparation of periodical reports directing attention to any new developments of interest or importance, including lists of subjects for which courses were run by overseas governments, the first such report to be prepared in about 18 months. In discussing the special staffing problems which arise from the development of the ministerial system and, in particular, its bearing on the tripartite relation between minister, permanent secretary and heads of departments, stress was laid on the importance of enabling professional officers to contribute fully in the formulation of policy and of respecting their professional integrity. It was also agreed that the professional branch of the Service should have the primary say in assessing the qualifications of the professional staff and their deployment. It also recognized that it was essential to build up proper administrative backing for the professional work, and in particular to ensure good staff relations with professional officers in the field when establishment work was undertaken by administrative and executive officers at headquarters.

\title{
FIELD-ALIGNED IONOSPHERIC IRREGULARITIES AND THE SCINTILLATION OF SATELLITE RADIO TRANSMISSIONS
}

\author{
By D. G. SINGLETON, G. J. E. LYNCH and D.. J. A. THOMAS \\ Department of Physics, University of Queensland, Brisbane
}

\begin{abstract}
$\mathrm{M}^{\mathrm{s}}$ ANY investigations have been made of the nature of the signals received from artificial Earth satellites ${ }^{1}$. These have shown that the amplitude of the signals may vary as the result of one or more of the following four causes : $(a)$ modulation of the satellite's transmitter; (b) rotation of the satellite antenna relative to the receiving antenna; (c) Faraday fading; (a) fading resulting from propagation through an irregular ionosphere. Suitable instrumentation can usually remove the results of cause $(a)$, while causes $(b)$ and $(c)$ together give rise to a regular fading component with a period of several seconds ${ }^{2}$ and can thus be recognized easily. The rapid and random fading is attributed to irregularities in the ionosphere, much the same mechanism being involved as is considered to be associated with the scintillation of radio stars.

Radio-star scintillations have been shown to be due to the passage of the radiation from the extraterrestrial source through an ionosphere which has clouds of enhanced ionization embedded in it ${ }^{3}$. Further, these clouds have been shown to have dimensions of the order of a kilometre and to be elongated along the direction of the Earth's magnetic field $^{4}$. There is considerable evidence, from groundbased radar investigations ${ }^{5}$ of the ionosphere, which also points to the existence of such field-aligned irregularities. Recently, Rush and Colin ${ }^{6}$ have con-
\end{abstract}

sidered the effect this anisotropy of the irregularities has on their ability to produce scintillations. They came to the conclusion that for propagation approximately along the field lines the scintillation activity normally associated with irregular diffraction by the irregular medium should be increased because of the possibility of radiation which traverses two completely different paths reaching the receiver. The first of these paths is the direct one; the second is vir grazing reflexion from the field-aligned irregularities. The geometry which they considered applies to parallel radiation from an extra-terrestrial source, but a similar effect would be expected to occur when the source is rather closer to the Earth's surface.

Observations of the radio transmissions of satellite 1959 Iota.1 (Explorer VII) made at Brisbane (dip. $57^{\circ}$ ) during the months of July, August and Septem. ber 1960, have been analysed in an attempt to estab. lish the existence of this effect. The satellite takes approximately $8 \mathrm{~min}$. to pass over the station and a scintillation index (fading amplitude/mean level) determined from the random fading component was allotted to each half minute of this period. From the known elements of the orbit it was possible to calculate, for each traverse, the time when the satellite passed through the observer's magnetic meridian plane. The scintillation index for the $\frac{1}{2}$-min. containing this time was then normalized according to the 